\section{Ozone hole looms large}

Washington \& London

BAD news is good news for four research teams conducting investigations into the depletion of stratospheric ozone in the Arctic. Polar stratospheric clouds (PSCs), containing the ice crystals thought to cause formation of active chlorine that destroys ozone, are forming in large numbers in the Arctic, which could result in a sizeable depletion of Arctic ozone this year. But they are forming within range of measuring equipment and aircraft, and data collected from these expeditions should confirm whether atmospheric ozone depletion is occurring in the Arctic.

The Canadian station at Alert at $82.6^{\circ}$ north latitude was able to record the first data. According to Wayne Evans of the Canadian Atmosphere Environment Service, the polar vortex was centred over Alert for much of January. The Canadian team has been using balloon-launched ozone sondes, backscatter sondes and water-vapour sondes to measure ozone levels and cloud-ice concentrations.

The location of the vortex was frustrating a team assembled by the US National Aeronautics and Space Administration working out of Stavanger, Norway (see Nature 337, 3; 1989) because it was out of range of the high-altitude ER-2 aircraft used by the team to fly into the stratospheric clouds. The US-led team was also experiencing difficulty with accurate weather forecasting for flying into the North Sea, according to NASA spokesman Charles Redmond. But now, according to Evans, the vortex has shifted towards Franz Josef Land on the Soviet side of the Arctic, and Redmond says both the ER-2 and the lower-flying DC-8 have completed 11 missions into areas where there are PSCs. Another four flights are planned before the team leaves Norway.

The movement of the vortex has put Soviet researchers in a prime position for studies from their base on Heiss Island, one of a group of islands in Franz Josef Land. According to Redmond, they are carrying out Dobson measurements of ozone and are believed to be sending balloons and aircraft into the vortex. Direct read-outs of their ozone soundings are being received at Stavanger.

Another international team, including groups from West Germany, France and the United States base at Kiruna in Northern Sweden, has also been busy making measurements in the polar vortex. They have made a number of successful balloon and rocket flights into the PSC-populated area, allowing measurements of ozone, stratospheric cloud particles and nitric acid.

Joseph Palca \& Philippa Lloyd

\title{
Political tide turns as threats to global climate develop
}

\section{Washington}

THE new US Secretary of State, James Baker, last week declared that the time has come for political action on the problem of global climate change. Baker's statement, made at the first meeting of a working group of the Intergovernmental Panel on Climate Change, is being interpreted as a major shift in US foreign policy. But Baker's call for action seems to have impelled the working group chiefly to follow US proposals and to establish bureaucratic procedures for future work.

Many of the themes at the meeting are familiar: the need for more research on renewable energy sources, renewed attention to nuclear power generation to reduce greenhouse-gas production, calls for added restrictions on ozone-damaging chlorofluorocarbon emissions and a campaign to halt deforestation.

But the draft report produced at the end of the closed three-day meeting does not address these matters, and instead outlines responsibilities for a steering group and four subgroups established at the meeting (energy and industry; other human activities; coastal zone management; and resource use and management). The only 'action' taken was a decision to ask the United States and the Netherlands to develop preliminary emission profiles for gases such as carbon dioxide and chlorofluorocarbons between now and the year 2100 for three scenarios: carbon dioxide equivalent doubling by 2030 ; doubling by 2050 ; and doubling by 2070 . Some delegates complained that the US proposal seemed at odds with Baker's statement and that it followed the former Reagan administration's practice of advocating more research and data collection before taking action. But Frederick Bernthal, assistant secretary of state, Bureau of International Environmental and Scientific Affairs, says the US proposal was "more ambitious" than the final draft adopted.

Meanwhile US politicians are moving ahead with their own agenda. Last week,

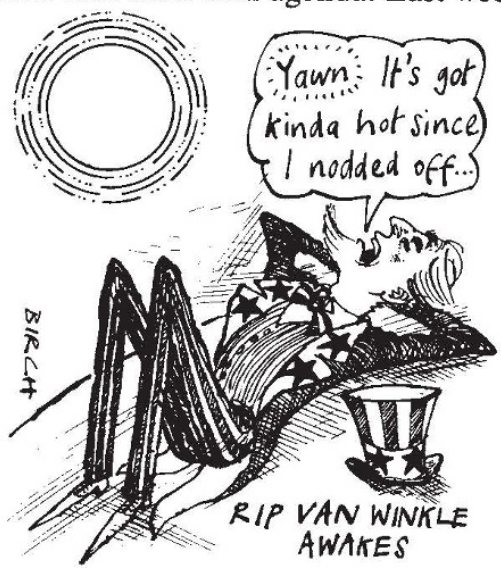

Senator Timothy Wirth (Democrat, Colorado) reintroduced legislation to establish a national energy policy to reduce emissions of greenhouse gases.

Late last month, Senator Ernest (Fritz) Hollings (Democrat, South Carolina), introduced the National Global Change Research Act to coordinate federal research on greenhouse warming, ozone depletion and other long-term environmental changes.

David Swinbanks

\section{Mounting opposition to UK student loans}

\section{London}

THE British government's plans to supplement student maintenance grants with loans have run into more opposition last week from the Committee of Vice-Chancellors and Principals (CVCP), which represents the common interests of British universities.

In a formal criticism of the loans scheme, announced only last November, the committee calls the plan "inadequate and unjust", fearing that students will be frightened away from longer courses (such as specialized engineering and teacher training) and from those leading to poorly paid vocations. It says the proposals are inconsistent with the need for the wider access to university education to which the government has recently been converted.

The committee says that it would in any case prefer a scheme in which graduates from higher education are taxed for a fixed period of years (provided that their salaries exceed the average), on the grounds that contributions by ex-students should be related to the value of their qualifications and not to the cost of providing them.

Commercial banks, which the government was relying on to administer the loans, also oppose the plan. The Department of Education and Science assumed that banks would subsidize the scheme in their enthusiasm to gain student customers. But the chief economic adviser to Lloyds Bank, Christopher Johnson, said this week that banks might actually lose student customers by becoming "debtcollectors" for the government. He proposes instead that conventional commercial loans be made to parents, with tax-free interest, and that both the government grant and parental contribution be increased by 18 per cent.

Christine McGourty 